\title{
EXPERIMENTAL STUDY ON STRENGTH CHARACTERISTICS OF CONCRETE WITH RECYCLED AGGREGATES AND ANALYSIS OF ITS EFFECTIVE USES IN ROAD WORKS
}

\author{
Visakh Suthan Pallath ${ }^{1}$, G.Gangha ${ }^{2}$, N.Ganapathy Ramasamy ${ }^{3}$ \\ ${ }^{1}$ Student M.tech, Construction Engineering and Management Civil Engineering Department, SRM University, Tamil \\ Nadu, India \\ ${ }^{2}$ Assistant Professor Civil Engineering Department SRM University, Tamil Nadu, India \\ ${ }^{3}$ Assistant Professor Civil Engineering Department SRM University, Tamil Nadu, India
}

\begin{abstract}
The objective of providing eco-friendly concrete is gaining hike in the global construction industry. The depleting resources have made the researchers to focus on sustainable development in all areas and more particularly in concrete production, due to the high rate of growth of industries and their infrastructure development, which increase the rate of consumption of concrete. The practice of recycling of demolished concrete for use in sub grades has already been set up. However a new concrete that is produced with such a recycled concrete seems to have higher porosity, lower strength and modulus of elasticity when compared to normal conventional concrete. Some of the earlier studies have attempted to improve the recycled material so as to reduce its high porosity. From review of literature it is found that studies under rural roads using recycled aggregates was done. This project deals with the use of recycled aggregates for rigid pavements replacing natural aggregates in rural roads. The tests are conducted for various proportion mix of Recycled aggregates and Natural aggregates.M $M_{30}$ grade of concrete is being used for the design. Aggregates at maximum size of $20 \mathrm{~mm}$ is taken. The required strength for rigid pavements under recycled aggregates is being evaluated in this project. The ultimate aim is to attain a suitable strength on usage of recycled aggregates for rigid pavements in rural roads thus to implement cost effective nature and durability.
\end{abstract}

Keywords: sustainable development, rigid pavements, recycled aggregates etc..

\section{INTRODUCTION}

Transport is a vital infrastructure for rapid economic growth of the country. Speedy transportation of natural resources (such as raw materials), finished goods and perishable materials to all parts of the country including the points of export outlets are basic inputs to economic growth. Recently there has been a major shift in transportation mode from Railways towards the Road sector. Now a day's about $60 \%$ of freight and $80 \%$ of passenger transport is met by Road transport in India, which demonstrates the need for development of a good road network. In India flexible pavement (bitumen) is most common for both national and state highways. Majority of roads are also built with conventional bitumen pavements considering its lower initial cost, though the life cycle cost of these pavements are very high compared to rigid pavements due to frequent repairs and also need for complete resurfacing at interval of 4-5 years. Further fuel consumption of vehicles is much higher on this type of pavement than that on rigid pavement. In advanced countries rigid pavement is increasingly being used due to large number of benefits it offers. Considering durability of concrete pavements some portion of Delhi Mathura and Mumbai - Pune expressway was built with jointed concrete pavement. Continuously reinforced concrete pavement, (CRCP) eliminates the need for transverse joints (other than at bridges and other structures) and keep cracks tight, resulting in a continuous, smoothriding surface that is virtually maintenance free.
The rural connectivity is expected to have many positive impacts on economy, agricultural, employment and social services to rural masses. The construction industry worldwide is using natural resources and disposing of construction and demolition waste to landfill in very large quantities. Both practices are damaging to the environment and are no longer considered sustainable at their current levels. Many governments throughout the world are therefore actively promoting policies aimed at reducing the use of primary resources and increasing reuse and recycling. One of the most environmentally responsible and economically viable ways of meeting the challenges of sustainability within the construction industry is the use of recycled concrete and demolition waste as aggregate. Road Connectivity is one of the key components for rural development, as it promotes access to economic and social services, generating increased agricultural income and productive employment. While building rural roads, the provisions based on the parameters that affect the sustainability are to be made, but at minimum cost. The conventional methods and specifications tend to recommend technology and materials, however difficult and distance away they may be, which normally result in higher cost of construction. It is the duty of the engineers to spend every rupee of the taxpayer's money with optional utility particularly under resource constraints. 
This call for introduction innovative approaches in rural roads building for achieving cost-effectiveness. Though such methods and technologies were tried world over, they could not become popular in India, due to procedural constraints and lack of awareness/exposure. At this juncture, an attempt is made to bring in together innovative technologies and discuss their positive impacts so as to convince the field engineers in adopting such technologies at placed found effective.

\section{OBJECTIVES AND SCOPE}

The objective of present work is to evaluate the influence of different levels of replacement of Natural Aggregate (NA) Recycled Concrete Aggregate (RCA). The scope of work is to evaluate the behaviour of recycled aggregate for the construction of rigid pavements for rural roads. The rigid pavements in rural roads has very good durability about 40 years and this makes its less maintenance to be done. The use of recycled aggregates in rural roads makes it cost effective.

\section{RESEARCH METHODOLOGY}

The methodology of the study is described and explained based on the objectives and the aims of the study. The use of recycled aggregates increasingly complex issues has prompted a refinement of methodologies. Products (aside from base course) are high quality aggregate, processed in steps with time and effort involved in crushing, pre-sizing, sorting, screening and contaminant elimination. The denominator is to start with clean, quality rubble in order to meet design criteria easily and ultimately yield a quality product that will go into end use.

Crushing and screening systems start with primary jaws, cones and/or large impactors taking rubble from 30 inches to 4 feet. A secondary cone or impactor may or may not need to be run, and then primary and secondary screens may or may not be used, depending upon the project, the equipment used and the final product desired. A scalping screen will remove dirt and foreign particles. A fine harp deck screen will remove fine material from coarse aggregate.Further cleaning is necessary to ensure the recycled concrete product is free of dirt, clay, wood, plastic and organic materials. This is done by water floatation, hand picking, air separators, and electromagnetic separators.Occasionally asphalt overlay or patch is found. A mixture of asphalt and concrete is not recommended but small patches are not detrimental.The more care that is put into the quality, the better product you will receive. With sound quality control and screening you can produce material without having to wash it as with virgin aggregate which may be ladened with clay and silt.

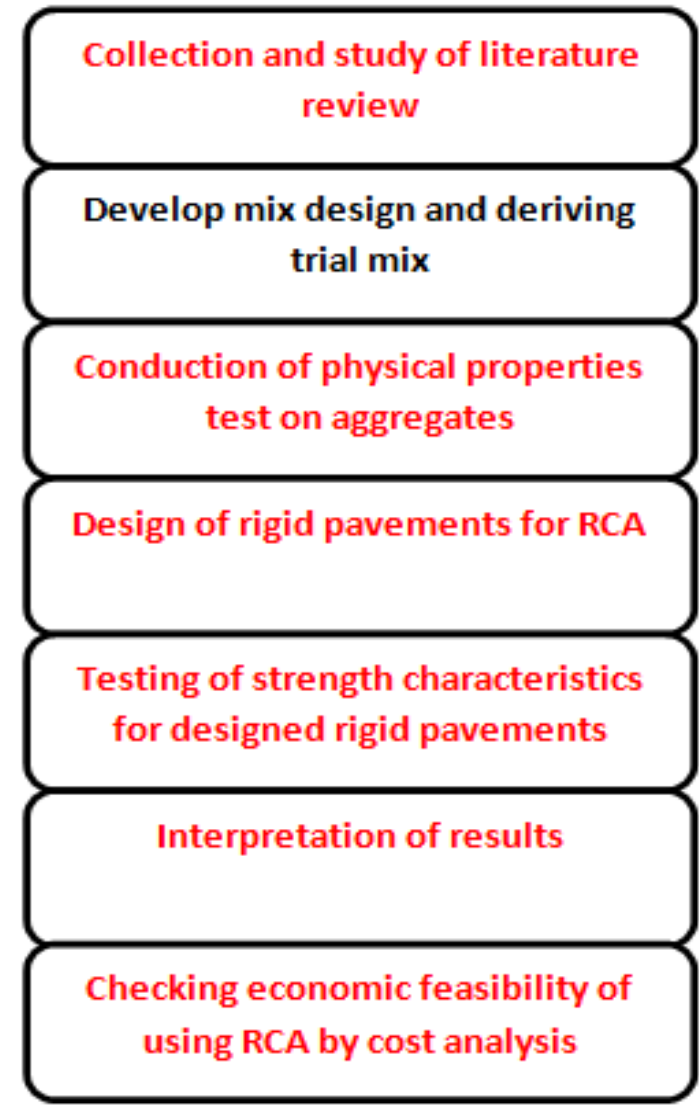

Fig 1: Flow chart of methodology

\section{EXPERIMENTAL INVESTIGATION}

\subsection{General}

Experimental investigations have been carried as per IS code standards.

\subsection{Properties of materials used}

The materials used for the present experimental work is discussed in the subsequent sections.

\subsubsection{Cement}

Ordinary Portland Cement (OPC) of 53 grade conforming to IS12269 : (1987) is used and its properties are given in Table 1

Table-1: Properties of cement

\begin{tabular}{|l|l|l|l|}
\hline No. & Property & Results & $\begin{array}{l}\text { Limiting } \\
\text { values as per } \\
\text { code } \\
\text { (is 12269 : } \\
1987)\end{array}$ \\
\hline 1. & $\begin{array}{l}\text { Fineness ( Air } \\
\text { permeability) }\end{array}$ & $\begin{array}{l}246.5 \\
\mathrm{~m}^{2} / \mathrm{Kg}\end{array}$ & $\begin{array}{l}\text { Not less } \\
\text { than 225 } \\
\mathrm{m}^{2} / \mathrm{Kg}\end{array}$ \\
\hline 2. & $\begin{array}{l}\text { Specific } \\
\text { gravity }\end{array}$ & 3.15 & $3.10-3.25$ \\
\hline 3. & $\begin{array}{l}\text { Standard } \\
\text { Consistency }\end{array}$ & $33 \%$ & $26 \%-35 \%$ \\
\hline
\end{tabular}




\begin{tabular}{|l|l|l|lr|}
\hline 4. & $\begin{array}{l}\text { Initial Setting } \\
\text { time Minutes }\end{array}$ & $\begin{array}{l}48 \\
\text { Minute } \\
\mathrm{s}\end{array}$ & $\begin{array}{l}\text { Not less } \\
\text { than } \\
\text { minutes }\end{array}$ \\
\hline 5. & $\begin{array}{l}\text { Compressive } \\
\text { Strength at 28 } \\
\text { days } \\
\left.\mathrm{N} / \mathrm{mm}^{2}\right)\end{array}$ & 55 & $\begin{array}{l}\text { Not less } \\
\text { than } \\
\mathrm{N} / \mathrm{mm}^{2}\end{array}$ \\
\hline
\end{tabular}

\subsubsection{Fine Aggregate}

Clean sand conforming to IS $383:$ (1970) is used. The results are shown in Table 2

Table 2: Properties of Fine Aggregate

\begin{tabular}{|l|l|l|l|}
\hline No. & Properties & Results & $\begin{array}{l}\text { Standard } \\
\text { values }\end{array}$ \\
\hline 1. & $\begin{array}{l}\text { Specific } \\
\text { Gravity }\end{array}$ & 2.74 & $2.6-2.85$ \\
\hline 2. & $\begin{array}{l}\text { Fineness } \\
\text { Modulus }\end{array}$ & 2.71 & $2.0-4.0$ \\
\hline
\end{tabular}

\subsubsection{Natural Coarse Aggregate (NCA)}

Natural angular aggregate of $20 \mathrm{~mm}$ ( maximum) size conforming to IS 383 : (19790) and its properties are given in Table 3

Table 3: Properties Of Natural Aggregates

\begin{tabular}{|l|l|l|l|l|}
\hline \begin{tabular}{l} 
No \\
\hline 1.
\end{tabular} & Property & $\begin{array}{l}\text { Resul } \\
\text { t }\end{array}$ & $\begin{array}{l}\text { Rang } \\
\text { e }\end{array}$ & $\begin{array}{l}\text { Referenc } \\
\text { e }\end{array}$ \\
\hline 2. & $\begin{array}{l}\text { Specific } \\
\text { gravity }\end{array}$ & 2.80 & $2.5-3$ & $\begin{array}{l}\text { IS 2386: } \\
1963 \\
\text { (Part 3) }\end{array}$ \\
\hline 3. & $\begin{array}{l}\text { Abrasion } \\
\text { value (\%) }\end{array}$ & 4.4 & $4-30$ & $\begin{array}{l}\text { IS 2386: } \\
1963 \\
\text { (Part 3) }\end{array}$ \\
\hline 4. & $\begin{array}{l}\text { Fineness } \\
\text { Modulus }\end{array}$ & 7.11 & $\begin{array}{l}6.5 \\
10\end{array}$ & $\begin{array}{l}\text { IS 386: } \\
1970 \\
\text { (Part 3) }\end{array}$ \\
\hline 5. & $\begin{array}{l}\text { Crushing } \\
\text { value (\%) }\end{array}$ & 20.3 & 20 & $\begin{array}{l}\text { IS 2386: } \\
1963 \\
\text { (Part 4) }\end{array}$ \\
\hline & $\begin{array}{l}\text { Impact } \\
\text { value (\%) }\end{array}$ & 16.5 & $\begin{array}{l}15 \\
30\end{array}$ & $\begin{array}{l}\text { IS 2386: } \\
1963 \\
\text { (Part 3) }\end{array}$ \\
\hline
\end{tabular}

\subsubsection{Recycled Aggregate (RCA)}

The aggregates are prepared by breaking already tested concrete cubes available at Structural Laboratory and are properly sieved and brought to size of $20 \mathrm{~mm}$ (Maximum) conforming to IS 383 : (1970) and IS 2386 (PT1): 1963 and their properties are given in Table 4.
Table 4: Properties Of Recycled aggregates

\begin{tabular}{|l|l|l|l|l|}
\hline No. & Properties & Result & Range & Reference \\
\hline 1. & $\begin{array}{l}\text { Specific } \\
\text { gravity }\end{array}$ & 2.66 & $\begin{array}{l}2.0- \\
3\end{array}$ & $\begin{array}{l}\text { IS 2386: } \\
\text { (Part 3) }\end{array}$ \\
\hline 2. & $\begin{array}{l}\text { Abrasion } \\
\text { value \% }\end{array}$ & 5.1 & $\begin{array}{l}\text { Above } \\
3 \%\end{array}$ & $\begin{array}{l}\text { IS 2386: } \\
1963 \\
\text { (Part 3) }\end{array}$ \\
\hline 3. & $\begin{array}{l}\text { Fineness } \\
\text { Modulus }\end{array}$ & 7.13 & $\begin{array}{l}6.5- \\
10\end{array}$ & $\begin{array}{l}\text { IS 386: } \\
\begin{array}{l}\text { (Part 3) } \\
\text { (Part }\end{array}\end{array}$ \\
\hline 4. & $\begin{array}{l}\text { Crushing } \\
\text { value \% }\end{array}$ & 22.5 & $\begin{array}{l}\text { Above 2386: } \\
20 \%\end{array}$ & $\begin{array}{l}\text { 1963 } \\
\text { (Part 4) }\end{array}$ \\
\hline 5. & $\begin{array}{l}\text { Impact } \\
\text { value \% }\end{array}$ & 14.63 & $\begin{array}{l}\text { Above } \\
12 \%\end{array}$ & $\begin{array}{l}\text { IS 2386: } \\
1963 \\
\text { (Part 3) }\end{array}$ \\
\hline
\end{tabular}

\subsubsection{Water}

Potable water available at college campus is used for mixing and curing.

\subsubsection{Comparison of Properties of Aggregates}

The comparison of the recycled and natural aggregates are mentioned in table 5

Table 5: Comparison Of Properties of Aggregates

\begin{tabular}{|l|l|l|l|l|}
\hline $\begin{array}{l}\text { No } \\
.\end{array}$ & Property & $\begin{array}{l}\text { NC } \\
\text { A }\end{array}$ & $\begin{array}{l}\text { RC } \\
\text { A }\end{array}$ & $\begin{array}{l}\text { Differenc } \\
\text { e }\end{array}$ \\
\hline 1 & $\begin{array}{l}\text { Specific } \\
\text { gravity }\end{array}$ & 2.8 & 2.66 & $5.0 \%$ \\
\hline 2 & $\begin{array}{l}\text { Abrasion } \\
\text { value \% }\end{array}$ & 4.4 & 5.1 & $15.9 \%$ \\
\hline 3 & $\begin{array}{l}\text { Fineness } \\
\text { modulus }\end{array}$ & 7.11 & 7.13 & $0.28 \%$ \\
\hline 4 & $\begin{array}{l}\text { Crushing } \\
\text { value \% }\end{array}$ & 20.3 & 22.5 & $5.40 \%$ \\
\hline 5 & $\begin{array}{l}\text { Impact } \\
\text { value \% }\end{array}$ & 16.5 & 14.6 & $11.33 \%$ \\
\hline
\end{tabular}

\section{MIX DESIGN}

The Mix adopted for this work is M30 Grade. The mix design is carried out as per IS method (IS 10262 : 1982) 
Table 6: Quantity Of Materials

\begin{tabular}{|c|c|c|c|}
\hline \multirow[t]{2}{*}{ No. } & \multirow[t]{2}{*}{ Material } & \multicolumn{2}{|c|}{$\begin{array}{l}\text { Quantity per } \mathrm{m}^{3} \text { in } \mathrm{kg} \text {. } \\
\mathrm{m30} \text { grade of concrete } \\
\text { using }\end{array}$} \\
\hline & & $\begin{array}{l}\text { Natural } \\
\text { aggregates } \\
\text { (NCA) }\end{array}$ & $\begin{array}{l}\text { Recycled } \\
\text { aggregates } \\
\text { (RCA) }\end{array}$ \\
\hline 1 & $\begin{array}{l}\text { Cement } \\
\left(\mathrm{Kg} / \mathrm{m}^{3}\right)\end{array}$ & 413 & 413 \\
\hline 2 & $\begin{array}{l}\text { Fine } \\
\text { aggregate } \\
\left(\mathrm{Kg} / \mathrm{m}^{3}\right)\end{array}$ & 980.50 & 980.50 \\
\hline 3 & $\begin{array}{l}\text { Coarse } \\
\text { aggregate } \\
\left(\mathrm{Kg} / \mathrm{m}^{3}\right)\end{array}$ & 1764 & 1675 \\
\hline 4 & $\mathrm{~W} / \mathrm{C}$ ratio & 0.45 & 0.45 \\
\hline
\end{tabular}

\subsection{Compressive Strength}

The concrete cube of size $150 \mathrm{~mm}$ x $150 \mathrm{~mm}$ using normal aggregates (9nos) and recycled aggregates (9nos) are tested as per IS516:1959 (Reaffirmed 1999).The results of compressive strength at the end of 7 days, 14 days and 28 days are taken.

Various mix proportions are taken for recycled aggregates

- $100 \%$ RCA

- $\quad 70 \% \mathrm{RCA}+30 \% \mathrm{NCA}$

- $\quad 50 \% \mathrm{RCA}+50 \% \mathrm{NCA}$

- $100 \% \mathrm{NCA}$

The compressive strength of natural and recycled aggregates are mentioned in table 7 and 8

Table 7: Compressive strength for $100 \%$ NCA and RCA

\begin{tabular}{|c|c|c|c|c|c|}
\hline \multirow[t]{2}{*}{ No } & \multirow[t]{2}{*}{ Mix } & \multirow[t]{2}{*}{$\begin{array}{l}\text { specime } \\
\text { n }\end{array}$} & \multicolumn{3}{|c|}{$\begin{array}{l}\text { compressive strength } \\
\mathrm{n} / \mathrm{mm}^{2}\end{array}$} \\
\hline & & & 7days & 14days & 28days \\
\hline \multirow[t]{4}{*}{1} & \multirow{4}{*}{$\begin{array}{l}100 \% \\
\text { NCA }\end{array}$} & 1 & 18.30 & 21.12 & 32.32 \\
\hline & & 2 & 19.15 & 22.31 & 31.25 \\
\hline & & 3 & 19.83 & 22.85 & 30.25 \\
\hline & & avg & 19.09 & 22.09 & 31.27 \\
\hline \multirow[t]{2}{*}{2} & \multirow[b]{2}{*}{$\begin{array}{l}100 \% \\
\mathrm{RCA}\end{array}$} & 1 & 17.45 & 20.16 & 29.17 \\
\hline & & 2 & 16.23 & 20.89 & 30.03 \\
\hline
\end{tabular}

\begin{tabular}{|l|l|l|l|l|l|}
\hline \multirow{2}{*}{} & 3 & 17.29 & 21.12 & 29.73 \\
\cline { 3 - 5 } & & avg & 16.99 & 20.72 & 29.64 \\
\hline
\end{tabular}

Table 8: Compressive strength of proportions

\begin{tabular}{|c|c|c|c|c|c|}
\hline \multirow[t]{2}{*}{ No } & \multirow[t]{2}{*}{ Mix } & \multirow[t]{2}{*}{$\begin{array}{l}\text { Specime } \\
\text { n }\end{array}$} & \multicolumn{3}{|c|}{$\begin{array}{l}\text { compressive strength } \\
\mathbf{n} / \mathrm{mm}^{2}\end{array}$} \\
\hline & & & 7days & 14days & 28days \\
\hline \multirow[t]{4}{*}{1} & \multirow{4}{*}{$\begin{array}{l}50 \% \\
\mathrm{NCA} \\
+ \\
50 \% \\
\text { RCA }\end{array}$} & 1 & 17.17 & 23.16 & 31.32 \\
\hline & & 2 & 18.19 & 23.11 & 30.61 \\
\hline & & 3 & 17.63 & 23.78 & 29.13 \\
\hline & & avg & 17.66 & 23.35 & 30.35 \\
\hline \multirow[t]{4}{*}{2} & \multirow{4}{*}{$\begin{array}{l}70 \% \\
\text { NCA } \\
+ \\
30 \% \\
\text { RCA }\end{array}$} & 1 & 19.67 & 23.09 & 33.15 \\
\hline & & 2 & 19.89 & 23.18 & 32.36 \\
\hline & & 3 & 20.03 & 23.27 & 30.79 \\
\hline & & avg & 19.86 & 23.18 & 32.10 \\
\hline
\end{tabular}

\section{RESULTS AND DISCUSSIONS}

Cube size of $150 \mathrm{~mm} \times 150 \mathrm{~mm}$ was used. The recycled aggregates were used from crushed demolished waste. These were dried and washed before the casting. The cement used was a 53 grade which showed a standard consistency of $33 \%$ with an intial setting time of 48 minutes. The compression test was evaluated as $55 \mathrm{~N} / \mathrm{mm}^{2}$. The fine aggregate showed an average specific gravity of 2.74 and a fineness modulus of 2.71 .

The comparison of recycled aggregate with respect to natural aggregate states that there is a high value for specific gravity for natural aggregates (2.8). The abrasion value for recycled aggregate is more than natural aggregates (5.1). The fineness modulus for both types of aggregates is almost the same as NCA is high. The crushing value and impact value is high for natural aggregates.

The compression test was carried out for all types of mixes $(70 \% \mathrm{NCA}+30 \% \mathrm{RCA})$ showed the maximum strength out of the four mixes. The compression strength was (32.10). The minimum strength shown was (100\%RCA) was (29.64). The variation of compression test is shown in the graph below. 


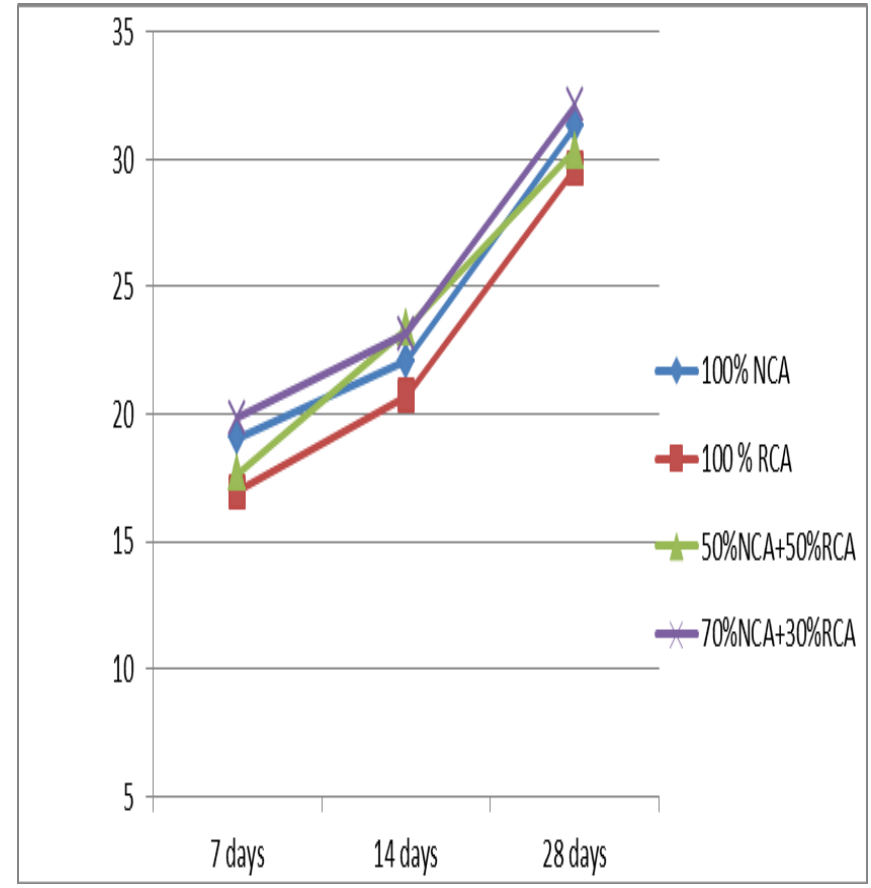

Chart 1: variation of compression strengths

\section{CONCLUSION}

The rural roads occupy less amount of traffic than highways therefore only limited amount of strength is required. The strength recommended for this exprerimental study was $30 \mathrm{~N} / \mathrm{mm}^{2}$.In the experimental investigation done it was shown that $(70 \% \mathrm{NCA}+30 \%)$ got the maximum strength of 32.10.This strength is much more than the required strength hence $(50 \% \mathrm{NCA}+50 \% \mathrm{RCA})$ is taken as the required strength 30.35 .

\section{REFERENCES}

[1]. J.R Jinemenz, (2004), 'Use of mixed recycled aggregates with a low embodied energy from non-selected CDW in unpaved rural roads ;Construction and Building Materials /34 (2012) 34-43.

[2]. Ahmed Ebrahim Abu El-Maat Behiry (2013), 'Utilization of cement treated recycled concrete aggregates as base or subbase layer in Egypt; Ain Shams Engineering Journal (2013) 4, 661-673.

[3]. Francisco Agrelaa,, Auxi Barbudoa (2012), 'Construction of road sections using mixed recycled aggregates treated with cement in Malaga, Spain; Resources, Conservation and Recycling 58 98- 106 .

[4]. Yoon-Ho Cho, et.al (2011), 'The Application of Recycled Concrete Aggregate (RCA) for Hot Mix Asphalt (HMA) base Layer Aggregate' KSCE Journal of Civil Engineering (2011) 15(3):473-478.

[5]. Gregory D. Cuttell, and Mark B. Snyder(2010), 'Performance of Rigid Pavements Containing Recycled Concrete Aggregates' transportation research record 1574 Paper No. 971071.

[6]. Jeff Roesler, Ph.D et .al. (2002) , 'Recycled Concrete Aggregate Concrete for Rigid Pavements at $\mathrm{O}$ Hare O'Construction and Building Materials 20, pgs.569577,2006
[7]. Chih-Ta Tsai a et.al (2001), 'Use of high performance concrete on rigid pavement construction for exclusive bus lanes' Construction and Building Materials 24 (2010) 732 740.

[8]. Marius-teodor muscalu and Radu Andrei (2011) 'Use of recycled aggregates in rigid pavement construction' Universities Technical Gheorghe Asachi” din IaşiTomul LVII (LXI), Fasc.2,2011.

[9]. Rajib B. Mallick (2014) 'Use of system dynamics for proper conservation and recycling of aggregates for sustainable road construction', Resources, Conservation and Recycling 86 (2014) 61-73.

[10]. M.S Shetty 'Concrete Technology' S.Chand vol1,1996

[11]. V.N Vazirani 'Hand Book of Civil Engineering'vol2,1993

[12]. IRC SP:62 -2004 'Guidelines for design and construction of cement concrete pavements for rural roads'.

\section{BIOGRAPHIES}

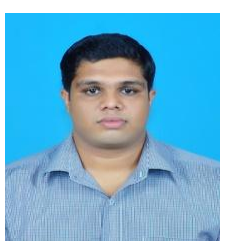

Mr. Visakh suthan pallath doing Mtec in construction engineering and management in SRM University Chennai, tamilnadu ,India

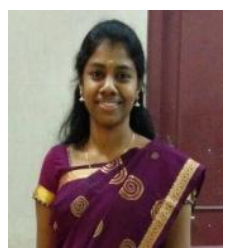

Ms. Gangha $\mathrm{G}$ is an assistant professor in transportation Engineering in SRM University Chennai, Tamilnadu ,India

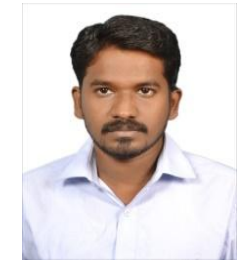

Mr. N.Ganapathy Ramasamy is an assistant professor in construction engineering and management in SRM University Chennai Tamilnadu, India 